\title{
SOSIALISME BUNG KARNO: MEMAHAMI IMAJINASI SOSIAL BUNG KARNO
}

\author{
RUDIYANTO $^{1}$
}

\begin{abstract}
This paper attempts to look at the ideas of Sukarno in regulating the nation with the theory of Social Imaginary. This theory speaks about portrayal of a nation through the eyes of the people. The portrayal is usually projected through legends, tales folktales and so forth. This paper saw Sukarno combines Western Social Imaginary with Social Imaginary of Indonesia to build a society of Indonesia. Sukarno then combines the concept of Internationalism to Nationalism. As well as the people's democracy or Marhaen with a conviction if people politically sovereign and eeconomically the nation will experience social justice.
\end{abstract}

Kata-Kata Kunci : Nasionalisme, Internasionalisme, Social Justice, Gagasan Sukarno, Imajinari Sosial

1 Pdt. Rudiyanto, M.Th. merupakan dosen teologi Universitas Kristen Satya Wacana, Salatiga. 


\section{PENDAHULUAN}

Ciapakah orang Indonesia yang sama sekali tidak mengetahui hal-ihwal Bung Karno? Salah seorang founding parents bangsa Indonesia, Bung Karno adalah seorang pemikir sekaligus politisi. Ia memimpin pergerakan nasional, menggali Pancasila dan mengusulkannya sebagai dasar negara, dan pernah menjadi presiden pertama negara Indonesia merdeka. Didampingi Bung Hatta, ia memproklamirkan kemerdekaan Indonesia pada tanggal 17 Agustus 1945.

Setelah Belanda menyerahkan kedaulatan kepada Indonesia (akhir 1949), Bung Karno tampil sebagai tokoh terkemuka sekaligus kontroversial di tataran internasional. Ia ikut menggagas Konferensi Asia Afrika (1955). Ia mengusulkan pembangunan dunia secara baru dengan Pancasila sebagai ideologi alternatif atas Kapitalisme dan Komunisme (1960). Ia turut memprakarsai gerakan NonBlok (1961). Ia juga berupaya menggalang kekuatan anti-imperialis sedunia yang dinamainya New Emerging Forces (1963).

Dalam tahun-tahun kekuasaannya yang nyaris mutlak (1959-1965), ia mencanangkan Sosialisme ala Indonesia sebagai visi bagi bangsanya serta menetapkan ajaran-ajarannya yang dinamai Panca Azimat Revolusi sebagai pedoman untuk mencapai visinya tersebut. Namun pada akhirnya, ia terguling dari kursi kekuasaan setelah gagal mempertahankan keseimbangan yang rapuh diantara kaum Komunis, Nasionalis serta Agamis.

Salah satu pemikiran Bung Karno yang paling menarik bagi penulis adalah pemikirannya tentang Sosialisme. Pemikiran tersebut dicetuskannya jauh sebelum ia berkuasa. Dengan pemikiran itu, Sukarno nyaris menciptakan dan mencanangkan sebuah Sosialisme ala Indonesia. Penulis, yang berhaluan Sosialis, merasa sangat terkesan mendapati salah seorang founding parents bangsa Indonesia memiliki gagasan yang serupa. Sebuah gagasan yang bahkan menjadi asas perjuangannya. Karena itu penulis merasa sangat tertarik untuk memahaminya. Dalam tulisan ini, pertama-tama penulis berupaya menyajikan gagasan Bung Karno tentang Sosialisme. Selanjutnya, penulis berupaya mengkaji gagasan tersebut dengan menggunakan teori imajinari sosial yang dipelajari penulis dari Charles Taylor (2004) dan Bernard Adeney-Risakotta (2012). Akhirnya, penulis coba melakukan refleksi teologis atas kajian tersebut.

\section{SOSIALISME BUNG KARNO}

Sukarno berpidato di hadapan BPUPKI (Badan Penyelidik Usaha Persiapan Kemerdekaan Indonesia) pada tanggal 1 Juni 1945. Pidato tersebut dikenal 
sebagai pidato Lahirnya Pancasila. Ia mempertautkan Kebangsaan dan Internasionalisme (Kemanusiaan) menjadi Sosio-nasionalisme. ${ }^{2}$ Sedangkan Demokrasi dan Keadilan Sosial menjadi Sosio-Demokrasi. ${ }^{3}$

Sosio-Nasionalisme adalah paham kebangsaan yang berkomitmen pada keadilan sosial dan persaudaraan antarmanusia. Sosio-Demokrasi adalah demokrasinya masyarakat atau demokrasinya rakyat, yakni kedaulatan rakyat baik atas politik maupun perekonomian. Bila rakyat berdaulat secara politik dan ekonomi, maka berakhirlah ketidakadilan sosial dan terwujudlah apa yang dinamakan tata tentrem kerta raharja, yang disebut bung Karno sebagai masyarakat sosialis ala Indonesia. Menurut bung Karno, itulah sesungguhnya yang harus dicapai di "seberang jembatan emas" kemerdekaan Indonesia. Lantas, siapakah yang dimaksud dengan "rakyat"?

Sepintas jawabannya sudah sangat jelas: rakyat adalah tiap-tiap orang yang menjadi warganegara Indonesia. Tapi bila kita menelusuri lebih jauh, kita akan mendapati bahwa terutama sekali Bung Karno mengartikan rakyat sebagai "Marhaen." Adapun yang dimaksud dengan Marhaen, menurut Bung Karno, adalah "kaum proletar Indonesia, kaum tani Indonesia yang melarat dan kaum melarat Indonesia yang lain-lain."

Karena itu, "sosio-nasionalisme adalah nasionalisme Marhaen"5, yang bermaksud "memperbaiki keadaan-keadaan di masyarakat itu, sehingga keadaan yang kini pincang itu menjadi keadaan yang sempurna, tidak ada kaum yang tertindas, tidak ada kaum yang celaka, tidak ada kaum yang papa-sengsara."6 Dengan kata lain, sosio-nasionalisme "adalah nasionalisme politik dan ekonomi, suatu nasionalisme yang bermaksud mencari keberesan politik dan keberesan ekonomi, keberesan negeri dan keberesan rezeki."7 Demikian juga sosiodemokrasi, yang dipahaminya sebagai "demokrasi yang sejati yang mencari keberesan politik dan ekonomi, keberesan negeri dan keberesan rezeki." ${ }^{8}$ Karena itu, sosio-demokrasi adalah "demokrasi politik dan demokrasi ekonomi." ${ }^{9}$

2 Sukarno, "Lahirnya Pancasila", dalam Bung Karno dan Tatanan Dunia Baru, eds., Iman Toto K. Rahardjo \& Herdianto WK (Jakarta: Grasindo, 2001), hlm. 25. Kata Bung Karno, “Dua dasar yang pertama, kebangsaan dan internasionalisme, kebangsaan dan perikemanusiaan, saya peras menjadi satu: itulah yang dahulu saya namakan socionasionalisme."

3 Ibid. Kata Bung Karno, "Demokrasi yang bukan demokrasi Barat, tetapi politiek-ekonomische democratie, yaitu politieke democratie dengan sociale rechtvaardigheid, demokrasi dengan kesejahteraan, saya peraskan pula menjadi satu: Inilah yang dulu saya namakan socio-democratie.

4 Sukarno, "Marhaen dan Proletar" (Fikiran Ra'jat, 1933), dalam Sukarno, Pokok-pokok Ajaran Marhaenisme menurut Bung Karno (Yogyakarta: Media Pressindo, 2002³), hlm. 13.

Sukarno, "Demokrasi-Politik dan Demokrasi-Ekonomi" (Fikiran Ra'jat, 1932), Ibid, hlm. 27.

Ibid.

Ibid.

Ibid.

Ibid. 
Menurut Bung Karno, sosio-nasionalisme dan sosio-demokrasi mendefinisikan Marhaenisme..$^{10}$ Bung Karno memaparkan,

“... bagi kita Marhaen Indonesia, azas kita adalah kebangsaan dan ke-Marhaen-an, sosio-nasionalisme dan sosio-demokrasi... Masyarakat yang nanti didirikan, haruslah masyarakat sosionasionalisme dan sosio-demokrasi, cara pemerintahan yang nanti kita jalankan adalah cara pemerintahan sosio-nasionalisme dan sosio-demokrasi, republik yang nanti kita dirikan adalah republik sosio-nasionalisme dan sosio-demokrasi, suatu republik politik sosial yang tiada kapitalisme dan tiada imperialisme."11

Tapi dalam Mencapai Indonesia Merdeka Bung Karno memperingatkan,

“... Indonesia merdeka hanyalah suatu jembatan, sekalipun suatu jembatan emas! yang harus dilalui dengan segala keawasan dan keprayitnaan, jangan sampai di atas jembatan itu kereta kemenangan dikusiri oleh orang lain selain Marhaen. Seberang jembatan itu jalan pecah jadi dua: satu ke dunia keselamatan Marhaen, satu ke dunia kesengsaraan Marhaen; satu ke dunia sama rata sama rasa, satu ke dunia sama ratap sama tangis. Celakalah Marhaen, bilamana kereta itu masuk ke atas jalan yang kedua, menuju ke alam kemodalam Indonesia dan keborjuisan Indonesia!"12

Karena itu, Bung Karno menyerukan,

“... Marhaen awas-awaslah! Jagalah yang kereta kemenangan nanti tetap di dalam kendalian kamu, jagalah yang politieke macht nanti jatuh ke dalam tangan kamu di dalam tangan besi kamu, di dalam tangan baja kamu!"13

10 Sukarno, "Marhaen dan Proletar," Ibid, hlm. 13.

11 Sukarno, "Azas; Azas Perjuangan; Taktik" (Fikiran Ra'jat, 1933), dalam Ibid, 36.

12 Sukarno, Mencapai Indonesia Merdeka (Jakarta: Yayasan Idayu, 2001²), hlm. 86.

13 Ibid. 
Bagaimana cara rakyat atau Marhaen menjaga atau mempertahankan kemenangan dan politieke macht atau kekuasaan politiknya? Jawab Bung Karno,

"Dengan demokrasi politik dan demokrasi ekonomi itu, maka nanti di seberangnya jembatan emas masyarakat Indonesia bisa diatur oleh rakyat sendiri sampai selamat, - dibikin menjadi masyarakat yang tiada kapitalisme dan imperialisme. Dengan demokrasi politik dan ekonomi itu, maka nanti Marhaen bisa mendirikan staat Indonesia yang tulen staat-nya rakyat - suatu staat yang segala urusannya politik dan ekonomi oleh rakyat, dengan rakyat, bagi rakyat." 14

Secara negatif, staat atau negara-nya rakyat itu

"Bukan sistem feodalisme... bukan sistem constitutioneel monarchie... bukan sistem republik yang sebagai di Prancis sekarang atau di Amerika sekarang yang sebenarnya suatu sistem republik daripada 'demokasinya' kapitalisme."15

Secara positif, negaranya rakyat itu merupakan

"sistem politiek economische republiek yang segala-gala tunduk kepada kecakrawartian rakyat."16

Persisnya,

"Urusan politik, urusan diplomasi, urusan onderwijs, urusan bekerja, urusan seni, urusan cultuur, urusan apa saja dan terutama sekali urusan ekonomi haruslah di bawah kecakrawartian itu: Semua perusahaan-perusahaan miliknya staat, - staat-nya rakyat, dan bukan staat-nya borjuis atau ningrat, - semua hasil-hasil perusahaan-perusahaan itu bagi keperluan rakyat, [sic!] Tidak

$14 \quad$ Ibid, 93-4.

15 Ibid, 94.

16 Ibid. 
boleh ada satu perusahaan lagi yang secara kapitalis menggemukan [sic!] kantong burgerlijke staat, tetapi masyarakatnya [sic!] Politiek Economische, Republik Indonesia adalah gambarnya satu kerukunan rakyat, satu pekerjaan bersama daripada rakyat, satu kesama-rasa sama-rataan daripada rakyat."17

\section{IMAJINARI SOSIAL}

Dalam bukunya, Modern Social Imaginaries, Charles Taylor mendefinisikan "imajinari sosial" sebagai ;

[C]ara-cara orang-orang membayangkan keberadaan sosial mereka, bagaimana mereka cocok bersama dengan orang lain, bagaimana hal-ihwal berlangsung di antara mereka dan sesama mereka, harapan-harapan yang terpenuhi secara wajar, dan gagasan-gagasan dan citra-citra normatif yang lebih mendalam yang mendasari harapan-harapan ini. ${ }^{18}$

Menurut Taylor, imajinari sosial berbeda dengan teori sosial. Imajinari sosial adalah cara orang-orang kebanyakan (ordinary people), bukan cara kaum intelektual, membayangkan keberadaan sosial mereka. "Cara membayangkan" itu termuat dan terungkap dalam simbol-simbol dan cerita-cerita (termasuk legenda-legenda, jadi bukan dalam makalah ilmiah). Hampir seluruh anggota komunitas/masyarakat, bukan segelintir orang, memiliki kesamaan dalam membayangkan keberadaan sosial mereka. Bagi mereka, "cara membayangkan" itu membuat praktik-praktik tertentu masuk akal, sah, dan bermakna.

Imajinari sosial ada pada tataran pra-reflektif, sedangkan teori sosial ada pada tataran post-reflektif. Pada tataran reflektif seorang intelektual (dalam hal ini ilmuwan/ilmuwati sosial) melakukan pengambilan jarak terhadap imajinari sosial, menganalisis, dan merenungkannya. Hasilnya, boleh jadi, adalah sebuah teori sosial. Teori imajinari sosial yang digagas Taylor, misalnya, adalah sebuah teori sosial tentang imajinari sosial.

17 Ibid.

18 Taylor, Modern Social Imaginaries, hlm. 23. 
Namun bisa juga sebuah teori sosial turut membentuk imajinari sosial. Teori Hugo Grotius tentang manusia sebagai agen-agen yang rasional dan berwatak sosial yang bisa bekerjasama secara damai guna kebaikan bersama, misalnya. Demikian juga teori Locke tentang pembatasan kekuasaan, teori Rousseau tentang kontrak sosial, dan teori Montesqueu tentang pembagian kekuasaan, dst. Semua teori itu turut membentuk imajinasi sosial, khususnya, masyarakat Barat. Demikianlah ada hubungan timbal-balik antara imajinari sosial dan teori sosial.

Imajinari (-imajinari) sosial Barat, menurut Taylor, ${ }^{19}$ berintikan harkat dan martabat individu dalam masyarakat. Tiap-tiap individu memiliki hak-hak tak tercerabut yang sama (hak-hak asasi manusia). Masyarakat dibentuk oleh individu-individu sebagai wadah kerjasama untuk memelihara dan memenuhi hak-hak tersebut dengan cara yang saling menguntungkan. Negara berikut sistem hukumnya adalah wujud politis masyarakat berdasarkan kontrak sosial. Tugasnya menjamin atau memastikan agar hak-hak tersebut terpelihara dan terpenuhi. Demikianlah, masyarakat dan negara ada untuk individu-individu yang menyusun dan menciptakannya.

Bernard Adeney-Risakotta mengembangkan imajinari (-imajinari) Barat-nya Taylor, dengan (1) menambahkan padanya kepercayaan terhadap gerak-maju perkembangan sosial;; dan (2) membandingkannya dengan imajinari sosial Indonesia ${ }^{21}$ (meski bisa dipertanyakan, apakah tidak lebih tepat dipandang sebagai "imajinari sosial Jawa" yang kemudian menjadi atau dijadikan imajinari sosial Indonesia). Penulis coba meringkaskan uraian Adeney-Risakotta tentang imajinari sosial Indonesia ${ }^{22}$ sebagai berikut.

Masyarakat adalah sebuah mikrokosmos, yang dimodel seturut dengan makrokosmos (Realitas Ultimat? - pen.). Makrokosmos tercermin dalam mikrokosmos melalui kehadiran hukum-hukum suci (baik tradisional maupun agamawi), hubungan-hubungan hierarkis (yang di dalamnya tiap-tiap orang mendapati diri dan fungsi atau kewajibannya), dan kekuatan-kekuatan gaib. Berkenaan dengan warganya, masyarakat adalah sebuah keluarga. Dalam keluarga besar ini, pemerintah (atau, untuk membuatnya paralel dengan imajinari sosial Barat) berkedudukan sebagai orang tua, sedangkan rakyat berkedudukan sebagai anak. Sebagai orang tua, pemerintah/negara dipandang bijaksana, menjadi panutan dan pengayom, serta menjamin kesejahteraan rakyat sebagai anak-anaknya.

\footnotetext{
$19 \quad$ Lihat Ibid, hlm. 19-22.

20 Bernard Adeney-Risakotta, "Imajinari Sosial Indonesia dan Barat", hlm. 92-93.

21 Ibid, hlm. 97-98.

22 Ibid, hlm. 105-116.
} 
Masyarakat dan pemerintah/negara wajib menaati hukum-hukum suci. Ketidaktaatan bisa mengganggu keseimbangan hubungan mikrokosmos dan makrokosmos, yang pada gilirannya mengancam kesejahteraan rakyat dan legitimasi pemerintah/negara. Ketika keseimbangan nyaris runtuh, yang ditandai dengan zaman edan (di mana masyarakat dilanda kekacauan yang sangat parah, sementara pemerintah/negara tidak berdaya), makrokosmos akan menyeimbangkannya kembali dengan menghadirkan Ratu Adil yang akan memulihkan segala sesuatu, memerintah dengan bijak dan adil, serta mewujudkan masyarakat adil makmur tata tentrem karta raharja. Dan begitu seterusnya.

Saya coba menambahkan sebagai berikut. Sebagaimana makrokosmos itu tunggal, begitulah kiranya mikrokosmos. Dalam pada itu, tidak disangkal bahwa dalam mikrokosmos terdapat keragaman. Namun, secara hakiki keragaman tersebut, baik keragaman agama, suku-bangsa, adat-istiadat, kedudukan sosial, dan ideologi, entah dipandang sebagai beragam wujud dari yang satu atau sebagai aneka jalan menuju yang satu. Ini mendasari sikap toleran dalam masyarakat. Meski demikian, sikap toleran ini ada batasnya juga. Batas tersebut adalah kehadiran "pihak sana" (bukan terutama dalam arti spasial, melainkan mental) yang dianggap sudah sangat merusak (misalnya penjajahan Belanda yang kulit putih atas Jawa/Indonesia yang kulit berwarna) atau akan sangat merusak (misalnya PKI) mikrokosmos tersebut. Bila sudah begitu, jawabannya berkisar pada perang besar ibarat Bharatayudha.

\section{SOSIALISME DAN IMAJINARI SOSIAL BUNG KARNO}

Berdasarkan dua imajinari sosial di atas, yakni Barat dan Indonesia (Jawa), bagaimana kita memahami Sosialisme-nya Bung Karno? Sebagaimana sudah dipaparkan di atas, Sosialisme-nya Bung Karno berintikan sosio-nasionalisme dan sosio-demokrasi, dan ketuhanan. Sosio-nasionalisme mengawinkan nasionalisme dan internasionalisme alias perikemanusiaan..$^{23}$

23 Dalam diskursus politik di Barat, keduanya kerap dipertentangkan, khususnya antara kalangan yang dianggap pro-kapitalisme dan kalangan yang berlabel Marxis. Dalam tahapan sejarah perkembangan ekonomi-politiknya, kaum borjuis mengibarkan panji nasionalisme. Sebabnya adalah karena perluasan kapital membutuhkan sokongan negara-bangsa. Di lain pihak, kaum Marxis, yang memandang diri sebagai representatif proletariat, mengibarkan panji internasionalisme. Sebabnya adalah karena di mana dan ke mana pun kapital bergerak, ia selalu menciptakan kelas yang dieksploitasinya, yakni kaum buruh alias kaum proletar. Tak heran bila organisasi perjuangan kaum buruh sedunia menamakan dirinya Internasional, demikian juga lagu perjuangannya. 
Di satu sisi, Bung Karno melihat bahaya nasionalisme tanpa internasionalisme: chauvinisme, yang dilihatnya pada "orang di Eropah yang mengatakan Deutschland uber Alles."24 Di sisi lain, ia juga menandaskan bahwa internasionalisme "tidak dapat hidup subur, kalau tidak berakar di dalam buminya nasionalisme." 25 Supaya sama-sama bebas dari penyakit masing-masing dan sama-sama sehat, keduanya harus dikawinkan. Kata Bung Karno, "Kita bukan saja harus mendirikan negara Indonesia Merdeka, tetapi kita harus menuju pula kepada kekeluargaan bangsabangsa." 26 Tidak memilih ini atau itu, melainkan memadukan ini dan itu dan menciptakan "sintesis yang lebih tinggi" (sebagaimana dilakukannya terhadap Nasionalisme, Islamisme, dan Marxisme), ${ }^{27}$ Kiranya memperlihatkan pengaruh imajinari sosial Jawa/Indonesia tentang Realitas Ultimat yang tunggal itu. Hasilnya adalah sejenis nasionalisme yang mencita-citakan keselamatan seluruh rakyat/ masyarakat serta menghubungkan bangsa Indonesia dengan bangsa-bangsa lain dengan semangat persahabatan dan persaudaraan.

Sosio-demokrasi mengawinkan demokrasi politik dan demokrasi ekonomi. Di Barat, demokrasi politik minus demokrasi ekonomi diidentifikasikan dengan borjuasi dan kapitalisme, sedangkan demokrasi politik dan demokrasi ekonomi diidentifikasikan dengan kaum Marxis - yang menyebut diri mereka kaum Sosial Demokrat. Bung Karno menciptakan (menggunakan) istilah sosio-demokrasi alih-alih Sosial Demokrasi. Hal ini menarik, di satu sisi ini memperlihatkan "utangnya" kepada Marxisme, dan dengan demikian pengaruh imajinasi sosial Barat yang memandang masyarakat sebagai wadah kerjasama bagi terpelihara dan terpenuhinya hak-hak asasi individual, yang bagi kaum Marxis meliputi juga pemerataan kesejahteraan/kemakmuran.

Di sisi lain, agaknya Bung Karno coba menjaga jarak, baik dengan demokrasi politik yang liberal atau parlementer (yang di Eropa sama-sama digunakan oleh borjuis/pro kapitalis dan oleh kaum Marxis), maupun dengan diktatur proletariat kaum Marxis Revolusioner alias Komunis (yang merosot menjadi diktatur birokratik Stalinis). Jelas, demokrasi politik dan demokrasi ekonomi berakar dalam imajinasi sosial Barat. Sebagai gantinya, Bung Karno menginginkan kekuasaan politik dan ekonomi Marhaen.

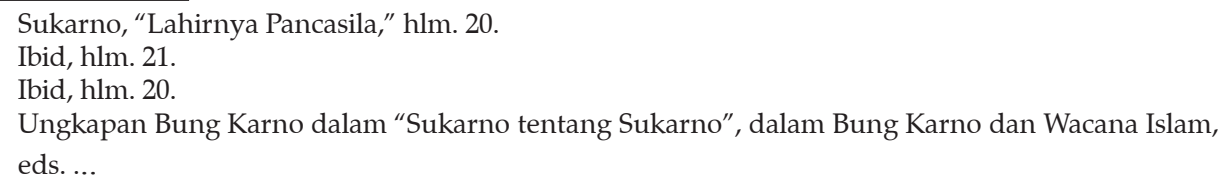


Sayangnya Bung Karno tidak pernah menguraikan bagaimana jelasnya kekuasaan politik dan ekonomi kaum Marhaen itu. Dalam kenyataannya, kaum Marhaen memang tidak pernah berkuasa dalam negara Indonesia Merdeka. Bahkan dengan "kembali kepada Undang-undang Dasar 1945", Bung Karno malah memberlakukan Demokrasi Terpimpin. Padahal, Demokrasi Terpimpin adalah "demokrasi" ala Jawa, yang menempatkan pemimpin sebagai bapak yang serba bijaksana, yang sanggup menampung berbagi aspirasi anak-anaknya serta membuat rumusan keputusan yang baik bagi semua pihak. Jelas, Bung Karno bukan sekadar meminjam gagasan Marxis tentang demokrasi politik dan demokrasi ekonomi. Seturut dengan imajinasi sosial Jawa/Indonesia-nya, Bung Karno memodifikasi gagasan tersebut.

Dari analisis imajinasi sosial, penulis mendapati bahwa Sosialisme Bung Karno merupakan suatu upaya untuk menyerap gagasan-gagasan yang lahir dari imajinasi sosial Barat ke dalam imajinasi sosial Jawa/Indonesia. Itu berarti, di satu sisi Bung Karno terbuka kepada gagasan-gagasan "luar"; di sisi lain, Bung Karno mengadaptasi gagasan-gagasan tersebut sesuai dengan imajinasi sosialnya.

\section{PENUTUP}

Upaya memahami Sosialisme Bung Karno dengan pendekatan imajinasi sosial mengingatkan saya pada Yesus dari Nazaret, yang tak lain dari Yesus Kristus, Tuhan dan Juruselamat saya. Tumbuh dan dibesarkan dalam masyarakat Yahudi yang hidup di bawah penindasan Romawi, Yesus berbagi imajinasi sosial yang sama dengan saudara-saudara sebangsanya: pengharapan akan kedatangan Sang Mesias yang akan membebaskan bangsa Yahudi/Israel dari penjajahan dan memulihkan kejayaan Raja Daud. Kendati demikian, agaknya Yesus berhasil mengambil jarak dengan imajinasi sosial tersebut.

Sementara kebanyakan messianic pretender sezaman menempuh rute yang kurang-lebih sama, yakni membentuk milisi guna menggelar perang kemerdekaan, Yesus menempuh rute yang sangat berbeda. Alih-alih membentuk milisi, Ia berupaya membentuk komunitas alternatif, yang diarahkan-Nya untuk hidup seturut dengan nilai-nilai Kerajaan Allah. Lewat komunitas alternatif ini Ia coba "menggarami" dan "menerangi" masyarakat. Orang melawan kekerasan tanpa kekerasan untuk memperlihatkan betapa absurdnya kekerasan 
dan mekanisme yang melahirkannya, yakni penindasan. Orang bebas datang kepada Allah dan menyapa-Nya sebagai Bapa tanpa bergantung pada sistem kurban yang dikelola oleh para imam di Kenisah. Orang kaya ditantang untuk mempersembahkan kekayaannya untuk melayani kaum miskin sebagai tanda pertobatan.

Dalam arti tertentu, komunitas ini subversif, merongrong status quo yang di dalamnya kelas-kelas penguasa (termasuk dari bangsa sendiri) beroleh keuntungan baik secara sosial, ekonomi, maupun politik. Tidak terlalu mengherankan bila akhirnya Yesus harus memeteraikan jalan yang ditempuhNya dengan kematian di tangan kelas-kelas penguasa yang merasa terancam. Meski demikian, kebangkitan-Nya memberi kesaksian bahwa Allah berkenan kepada jalan yang ditempuh Yesus. Tak lama sesudah kematian-Nya, sejumlah besar orang bergabung dengan komunitas-Nya, dan menawarkan alternatif kepada masyarakat luas - dari Yerusalem, Yudea, Samaria, dan ujung bumi.

Sepertinya tidak ada kaitan antara gerakan Yesus dan Sosialisme Bung Karno. Tapi kita bisa menemukan dua cara dalam "menangani" imajinasi sosial. Bung Karno berani mempertemukan imajinasi sosial Jawa/Indonesia dengan imajinasi sosial Barat, khususnya sebagaimana terungkap dalam gagasan-gagasan Marxis. Dalam perjumpaan itu, imajinasi sosial Jawa/Indonesia menyerap gagasan-gagasan Marxis. Jadilah Sosialisme Bung Karno. Dengan jalan itu, betapa dahsyatnya "sintesis" Bung Karno membangkitkan semangat kaum Marhaen Indonesia.

Di lain pihak, Yesus berani memodifikasi imajinasi sosial tentang Mesianisme. Meski harus memeteraikan "eksperimen"-Nya dengan kematian-Nya sendiri, pada gilirannya Yesus berhasil menciptakan komunitas alternatif yang hidup seturut dengan modifikasi-Nya. Eksperimen Yesus menjadi imajinasi sosial yang baru.

Sebagai seorang Kristen, yang berhaluan Sosialis (bukan Komunis), penulis belajar dari kedua tokoh ini: berani membuka diri kepada gagasan-gagasan baru untuk memperkaya imajinasi sosial sendiri dan berani memodifikasi imajinasi sosial sendiri dalam ketaatan kepada Allah dan kesediaan melaksanakan rencana-Nya. ${ }^{* * *}$ 


\section{DAFTAR PUSTAKA}

Sukarno, "Lahirnya Pancasila", dalam Bung Karno dan Tatanan Dunia Baru, eds., Iman Toto K. Rahardjo \& Herdianto WK. Jakarta: Grasindo, 2001.

Sukarno, "Marhaen dan Proletar" (Fikiran Ra'jat, 1933), dalam Sukarno, Pokokpokok Ajaran Marhaenisme menurut Bung Karno. Yogyakarta: Media Pressindo, 2002

Sukarno, "Demokrasi-Politik dan Demokrasi-Ekonomi" (Fikiran Ra'jat, 1932)

Sukarno, "Azas; Azas Perjuangan; Taktik" (Fikiran Ra'jat, 1933)

Sukarno, Mencapai Indonesia Merdeka. Jakarta: Yayasan Idayu, $2001^{2}$

Taylor, Charles, Modern Social Imaginaries. Durham \& London: Duke University Press, 2004.

Bernard Adeney-Risakotta, "Imajinari Sosial Indonesia dan Barat", dalam Bernard Adeney-Risakotta, ed., Mengelola Keragaman di Indonesia. Bandung: Mizan, 2012. 